\title{
Comparison of radiographic appearances with associated pathology and lung dust content in a group of coalworkers
}

\author{
V ANNE RUCKLEY, ${ }^{1}$ JUNE M FERNIE, ${ }^{1}$ J S CHAPMAN,${ }^{1}$ PAULA COLLINGS, ${ }^{1}$ \\ J M G DAVIS, ' A N DOUGLAS, ${ }^{1}$ D LAMB, ${ }^{2}$ AND A SEATON ${ }^{\prime}$
}

From the Institute of Occupational Medicine, ${ }^{1}$ Edinburgh, and the Department of Pathology, ${ }^{2}$ University of Edinburgh Medical School, Edinburgh, UK

\begin{abstract}
The pathology and dust content of lungs from 261 coalminers in relation to the appearances of their chest radiographs taken within four years of death were examined. Radiological opacities of coalworkers' pneumoconiosis were more profuse the more dust was retained in lungs. Among the men who had mined low rank coal-that is, with a relatively high proportion of ash-the increase in profusion was most closely related to the ash component of the dust, whereas in men who had mined high rank coal both coal and ash increased in the lungs in relation to radiological profusion. The fine $\mathrm{p}$ type of opacity was found to be associated with more dust and a higher proportion of coal and less ash than the nodular $r$ opacity, and was also more likely to be associated with emphysema. The pathological basis of the different types of opacity found on the radiographs of coalminers related to the number, size, and nodularity of the dust lesions. Larger fibrotic lesions were likely to appear as $\mathrm{r}$ opacities, whereas fine reticular dust deposition was most likely to present as $\mathrm{p}$ opacities, $\mathrm{q}$ opacities showing a mixture of appearances. The study has shown that the composition of dust retained in the lung, as well as its amount, makes an important contribution to the radiographic appearances of pneumoconiosis. In particular, the $r$ type of lesion on the radiograph of a low rank coalminer indicates the possibility of a silicotic like lesion.
\end{abstract}

The relation between exposure to coalmine dust and the radiographic profusion of small opacities in simple pneumoconiosis has been well documented. ${ }^{1-3}$ The primary relation appears to be with exposure to mixed respirable dust, and no generally applicable additional effect of the ash component of the dust has been shown. ${ }^{3}$ Consequently it seems logical to suppose that radiographic opacities are due largely to an accumulation of dust and, indeed, such an association between retained dust and profusion of opacities has been clearly shown. ${ }^{45}$

Most workers, however, describe groups in which the radiological changes appear disproportionate for the amount of dust in the lungs and recognise that factors other than the mass of retained dust contribute to the radiographic picture. It has been noted, for example, that the higher the proportion of coal

Received 6 June 1983

Accepted 7 November 1983 in the retained dust, the more dust is required to produce a given radiological category, ${ }^{6}$ and Caplan found that the radiological category was more closely associated with the profusion of fibrotic nodules in the lung than with the profusion of dust foci of all types.?

The principal aim of the present study was to examine further the factors that affect the relation between the profusion of small opacities and the mass of retained lung dust. Additional aims were to determine the pathological basis for the three types of small rounded opacity and to verify the reported association of both the $p$ type of small rounded opacity $^{8}$ and irregular opacities ${ }^{9}$ with the presence of emphysema.

\section{Methods}

SOURCE AND CLASSIFICATION OF RADIOGRAPHS The study was based on 261 men drawn from a group of 500 coalworkers, all of whom had been 
employed at collieries included in the pneumoconiosis field research of the National Coal Board and whose lungs were collected for a necropsy study. The pneumoconiosis medical panels were the source of $95 \%$ of the lungs. In terms of the pneumoconiosis field research population from which they were drawn, men in the necropsy study were older and more severely diseased but nevertheless they covered the full range of dust associated disease. Selection for this study was dependent on the availability of a chest radiograph taken within four years of death, and men thus selected were representative of the 500 for distribution over coal rank, age range, and pathological severity. Radiographs were obtained from pneumoconiosis medical panels or from hospitals, or were taken during the periodic field research surveys.

The radiographs (one for each man) were randomised and read in two batches by experienced Coal Board medical officers; five readers were present on the first occasion, four on the second. Readings were made according to the 1971 ILO U/C classification $^{10}$ whereby the profusions of rounded and irregular small opacities are recorded on a 12-point incremental scale together with the predominant type of opacity, and large opacities $(>1$ $\mathrm{cm})$ are recorded in three size categories.

Average readings, where reported, were based on the records of four doctors who were present at both reading sessions and were derived as follows. The ILO 12-point scale for the profusion of small opacities was converted to a 12-point notional scale of -1 to +10 . The notional scale scores for each reader were summed and a mean score was assigned to the radiograph. Opacity types, determined by their size, were recorded using two characters - for example, pr, qq for small rounded opacities. Taking the first letter of the pair the most frequently occurring value of these readings was used as the "average." In cases where an even split in reading occurred the pneumoconiosis field research identification number was used as a random tie breaker, an odd number resulting in the smaller type classification being assigned.

The main results of the investigation are shown for five radiographic readers. Details of dust values are shown for a single observer (reader 3) chosen as best illustrating the trends observed. Data generated for all readers are available elsewhere."

\section{LUNG EXAMINATION}

For 50 radiographs, at least three of the four readers were in agreement that the small rounded opacity type was pp, qq, or rr. From this group a consultant chest physician (AS) selected zones on the chest radiographs which displayed opacities typical of the three types and for which lung tissue was available for examination. Twenty four subjects were selected in this way, to which were added seven with normal $(0 / 0)$ radiographs giving 53 zones for examination.

Four observers, working independently, examined the same sagittal lung slice from each of the 31 subjects without knowledge of the radiological classification. Lung slices were orientated as though within the upright chest, and the distance between the apex and the base was divided horizontally into three equal parts to correspond with the radiographic zones. Thread was attached to the edge of the lung at either end of the demarcation of the zone, being long enough on one side to be stretched across to delineate zones in a comparable manner for each observer. Three observers undertook lung examinations on two occasions separated by several weeks, the fourth was present on only one occasion.

Within the preselected zones all foci of dust deposition were counted and the number of nodules, defined as having a solid centre of $1 \mathrm{~mm}$ or more, was recorded using three size ranges $<1.5 \mathrm{~mm}, 1.5$ $-3 \mathrm{~mm}$, and $>3 \mathrm{~mm}$. Three shapes of nodule were recognised, those with a small central region surrounded by elongated strands of emphysematous tissue (type a), those with a larger central region surrounded by shorter peripheral strands (type b), and rounded lesions (type c); the predominant type for each zone was recorded. The extent of emphysema on each lung slice was estimated using a method $^{11}$ based on that of Heard. ${ }^{12}$

One or more histological sections were available for each zone examined. Sections were stained with haematoxylin and eosin, and by the methods of Van Gieson and Gordon and Sweet for collagen and reticulin respectively, and were reviewed independently by two of the four observers.

\section{DETERMINATION OF LUNG DUST CONTENT}

One lung of each pair was used for measurement of dust content. Dust was recovered from representative samples of dried lung by the method of Guest. ${ }^{13}$ Recovered dust was ashed to constant weight, coal content being measured by weight loss. Residual ash was analysed for quartz, kaolin, and mica by infrared spectrophotometry. ${ }^{14}$ A figure for the dust content of both lungs was calculated by multiplying the measured weight in a single lung by 2.16 when the left lung was analysed, and by 1.86 for the right lung. The corrective factors were determined using the average weights of dust in left and right lungs from 490 subjects.

At times in this paper there is reference to the "rank" of coal, a descriptive term for the position on the geological "coalification" scale (from lignite to anthracite), increasing rank being associated with 
Comparison of radiographic appearances with associated pathology and lung dust content in a group of coalworkers

diminishing "volatiles" and increasing carbon content. Subjects were divided into "high" and "low" rank groups depending on the rank of coal mined at the pit where each man had worked, the carbon content of the coal being above and below $88 \%$ respectively.

\section{Results}

\section{ASSOCIATIONS BETWEEN RETAINED DUST AND} THE PROFUSION OF SMALL ROUNDED OPACITIES IN SIMPLE PNEUMOCONIOSIS

Subjects categorised as having large radiographic opacities $(>1 \mathrm{~cm})$ by the individual reader were excluded and in the remainder the profusion scores for small rounded opacities (SRO) were reduced to a four point scale giving categories $0,1,2$, and 3 .

The mean weight of retained dust and its measured components coal, ash, quartz, and kaolin plus mica increased over the profusion range. The differences were statistically significant (F-test of equality of means) for each component and for all readers. Figure 1 illustrates the association between lung dust and profusion of small rounded opacities for five readers. The composition of retained dust, in percentage terms, did not vary consistently with profusion category.

When subjects were divided into high and low rank groups the observed increase in mean lung dust content with rising profusion category was evident for both but was more striking in the high rank group (table 1). At category 0 , the dust content of the lung was similar for both groups but at category 3 , lungs in the high rank group contained, on average, twice as much dust as those from the low rank group.

In the high rank group both coal and ash contributed to the overall increase in lung dust content whereas in low rank subjects the increase was largely accounted for by an increase in the ash content of the dust (table 2). Depending on the reader this increase seemed either to be distributed over

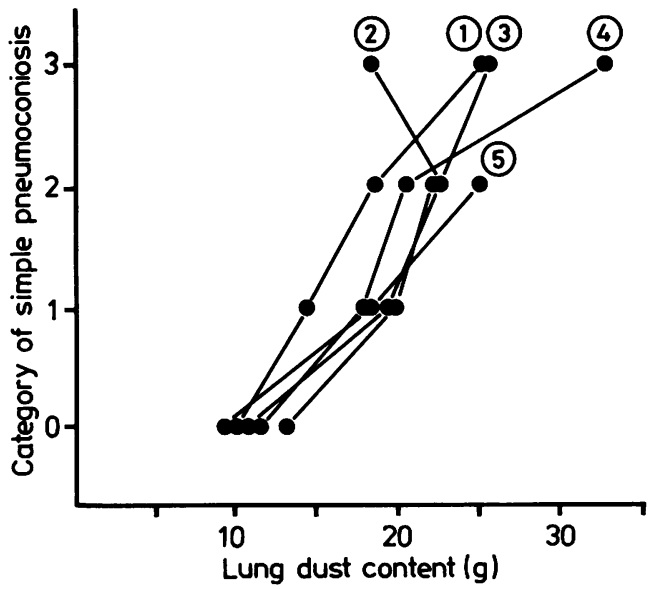

Fig 1 Mean lung dust content for each category of simple pneumoconiosis shown for five* readers identified by number.

${ }^{*}$ Reader 5 classified 118 of 261 cases.

the whole category range or to occur between categories 0 and 1.

\section{ASSOCIATIONS BETWEEN RETAINED DUST AND TYPE OF SMALL ROUNDED OPACITY}

On average, $40 \%$ of the 261 radiographs showed no small rounded opacities (category 0 ). Of the remainder, $\mathrm{q}$ opacities were the most commonly recorded accounting for $61 \%$, whereas $\mathrm{r}$ opacities were least common being found in $11 \%$ of subjects. About half the radiographs showing predominantly p or $\mathrm{q}$ opacities also showed progressive massive fibrosis (PMF). Between $77 \%$ and $100 \%$ of the radiographs with predominantly $r$ opacities showed PMF (depending on the reader).

Within the study group only four specimens were regarded pathologically as showing Caplan's syndrome. These were almost exclusively described as showing $r$ opacities and were removed before further data analysis on the grounds that they might

Table 1 Mean weight of retained dust (and standard deviation) for each profusion category of small rounded opacity divided by coal rank

\begin{tabular}{|c|c|c|c|c|c|c|c|c|c|}
\hline $\begin{array}{l}\text { Coal } \\
\text { rank }\end{array}$ & $\begin{array}{l}\text { Radiographic } \\
\text { category }\end{array}$ & $\begin{array}{l}\text { Reader } \\
\text { No of } \\
\text { men }\end{array}$ & $\begin{array}{l}1 \\
\text { Mean lung dust } \\
(g)\end{array}$ & $\begin{array}{l}\text { Reader } \\
\text { No of } \\
\text { men }\end{array}$ & $\begin{array}{l}\text { Mean lung dust } \\
(g)\end{array}$ & $\begin{array}{l}\text { Reader } \\
\text { No of } \\
\text { men }\end{array}$ & $\begin{array}{l}3 \\
\text { Mean lung dust } \\
\text { (g) }\end{array}$ & $\begin{array}{l}\text { Reader } \\
\text { No of } \\
\text { men }\end{array}$ & $\begin{array}{l}4 \\
\text { Mean lung dust }\end{array}$ \\
\hline High & $\begin{array}{l}0 \\
1 \\
2 \\
3\end{array}$ & $\begin{array}{r}86 \\
12 \\
9 \\
1\end{array}$ & $\begin{array}{l}13.4(10.2) \\
20.6(8 \cdot 1) \\
26.0(12 \cdot 5) \\
37.7\end{array}$ & $\begin{array}{r}61 \\
20 \\
9 \\
-\end{array}$ & $\begin{array}{l}10.7(8 \cdot 9) \\
20.6(9 \cdot 0) \\
24 \cdot 0(14 \cdot 1)\end{array}$ & $\begin{array}{r}52 \\
12 \\
24 \\
3\end{array}$ & $\begin{array}{l}10.4(8 \cdot 5) \\
17 \cdot 1(10 \cdot 3) \\
20.3(9 \cdot 8) \\
41 \cdot 3(7 \cdot 1)\end{array}$ & $\begin{array}{r}70 \\
24 \\
4 \\
2\end{array}$ & 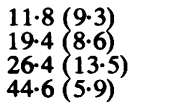 \\
\hline Low & $\begin{array}{l}0 \\
1 \\
2 \\
3\end{array}$ & $\begin{array}{r}67 \\
16 \\
6 \\
1\end{array}$ & $\begin{array}{l}12 \cdot 3(9 \cdot 2) \\
20-0 \\
17 \cdot 2(7 \cdot 1) \\
15 \cdot 8\end{array}$ & $\begin{array}{r}51 \\
15 \\
4 \\
5\end{array}$ & $\begin{array}{l}11.0(8.5) \\
18.6(11.4) \\
19.5(5.4) \\
18.2(8.0)\end{array}$ & $\begin{array}{r}28 \\
19 \\
17 \\
8\end{array}$ & $\begin{array}{r}9.3(8 \cdot 6) \\
12.7 \\
15 \cdot 7(7 \cdot 3) \\
19.8(6 \cdot 3)\end{array}$ & $\begin{array}{r}47 \\
32 \\
8 \\
2\end{array}$ & $\begin{array}{l}11 \cdot 2(8 \cdot 0) \\
16 \cdot 6(10 \cdot 1) \\
17 \cdot 5(4 \cdot 0) \\
21 \cdot 4(14 \cdot 6)\end{array}$ \\
\hline
\end{tabular}

${ }^{*}$ Reader 5 had only six men at category 2 or above and was excluded. 
Table 2 Mean retained lung dust by weight and percentage composition for each profusion category of small rounded opacity divided by coal rank (differences examined by $F$ test)_reader 3

\begin{tabular}{|c|c|c|c|c|c|c|c|c|c|c|}
\hline $\begin{array}{l}\text { Radiographic } \\
\text { category }\end{array}$ & $\begin{array}{l}\text { No of } \\
\text { men }\end{array}$ & $\begin{array}{l}\text { Total } \\
\text { dust }(g)\end{array}$ & $\begin{array}{l}\text { Total } \\
\text { coal }(g)\end{array}$ & $\begin{array}{l}\text { Total } \\
\text { ash }(g)\end{array}$ & $\begin{array}{l}\text { Total } \\
\text { quartz (g) }\end{array}$ & $\begin{array}{l}\text { Total kaolin } \\
+ \text { mica }(g)\end{array}$ & $\%$ Coal & \% Ash & \% Quartz & $\begin{array}{l}\% \text { Kaolin + } \\
\text { mica }\end{array}$ \\
\hline \multicolumn{11}{|c|}{ High rank } \\
\hline $\begin{array}{l}0 \\
1 \\
2 \\
3 \\
\text { Standard deviation } \\
\text { F value } \\
\text { p value }\end{array}$ & $\begin{array}{r}52 \\
12 \\
24 \\
3\end{array}$ & $\begin{array}{l}10 \cdot 3 \\
17 \cdot 1 \\
20 \cdot 3 \\
41 \cdot 3 \\
11 \cdot 1 \\
15 \cdot 9 \\
<0 \cdot 001\end{array}$ & $\begin{array}{c}7 \cdot 8 \\
14 \cdot 0 \\
16 \cdot 2 \\
35 \cdot 6 \\
9 \cdot 6 \\
17 \cdot 2 \\
<0 \cdot 001\end{array}$ & $\begin{array}{l}2 \cdot 6 \\
3 \cdot 1 \\
4 \cdot 1 \\
5 \cdot 7 \\
2 \cdot 1 \\
5 \cdot 3 \\
<0 \cdot 01\end{array}$ & $\begin{array}{l}0.4 \\
0.5 \\
0.6 \\
0.7 \\
0.3 \\
4.8 \\
<0.01\end{array}$ & $\begin{array}{l}1 \cdot 8 \\
2 \cdot 2 \\
2.9 \\
4 \cdot 5 \\
1 \cdot 5 \\
6 \cdot 5 \\
<0.001\end{array}$ & $\begin{array}{l}75 \cdot 1 \\
79 \cdot 6 \\
74 \cdot 3 \\
85 \cdot 5 \\
12 \cdot 1 \\
1 \cdot 2 \\
\text { NS }\end{array}$ & $\begin{array}{l}24 \cdot 9 \\
20 \cdot 4 \\
25 \cdot 7 \\
14 \cdot 5 \\
12 \cdot 1 \\
1 \cdot 2 \\
\text { NS }\end{array}$ & $\begin{array}{l}3 \cdot 8 \\
3 \cdot 1 \\
3 \cdot 5 \\
1 \cdot 8 \\
1 \cdot 7 \\
1 \cdot 5 \\
\text { NS }\end{array}$ & $\begin{array}{c}17 \cdot 5 \\
14 \cdot 5 \\
15 \cdot 7 \\
11 \cdot 6 \\
6 \cdot 8 \\
1 \cdot 4 \\
\text { NS }\end{array}$ \\
\hline $\begin{array}{l}0 \\
1 \\
2 \\
3 \\
\text { Standard deviation } \\
\text { F value } \\
\text { p value }\end{array}$ & $\begin{array}{r}28 \\
19 \\
17 \\
8\end{array}$ & $\begin{array}{c}9 \cdot 3 \\
12 \cdot 7 \\
15 \cdot 7 \\
19 \cdot 8 \\
8 \cdot 6 \\
4 \cdot 5 \\
<0.01\end{array}$ & $\begin{array}{l}5 \cdot 8 \\
7 \cdot 0 \\
7 \cdot 3 \\
8 \cdot 9 \\
6 \cdot 0 \\
0 \cdot 6 \\
\text { NS }\end{array}$ & $\begin{array}{c}3 \cdot 5 \\
5 \cdot 7 \\
8 \cdot 4 \\
10.9 \\
4 \cdot 7 \\
9 \cdot 8 \\
<0.001\end{array}$ & $\begin{array}{c}0.6 \\
0.9 \\
1.5 \\
2.0 \\
0.8 \\
10.4 \\
<0.001\end{array}$ & $\begin{array}{c}2.1 \\
3 \cdot 7 \\
5 \cdot 4 \\
7 \cdot 3 \\
3 \cdot 2 \\
10 \cdot 5 \\
<0.001\end{array}$ & $\begin{array}{c}56 \cdot 9 \\
56 \cdot 7 \\
48 \cdot 2 \\
44 \cdot 1 \\
16 \cdot 3 \\
2 \cdot 2 \\
\text { NS }\end{array}$ & $\begin{array}{c}43 \cdot 1 \\
43 \cdot 3 \\
51 \cdot 8 \\
55 \cdot 9 \\
16 \cdot 3 \\
2 \cdot 2 \\
\text { NS }\end{array}$ & $\begin{array}{r}7 \cdot 6 \\
7 \cdot 1 \\
9 \cdot 2 \\
10 \cdot 2 \\
3 \cdot 7 \\
2 \cdot 0 \\
\text { NS }\end{array}$ & $\begin{array}{c}25.9 \\
28.5 \\
32.3 \\
37.4 \\
11.0 \\
3.0 \\
<0.05\end{array}$ \\
\hline
\end{tabular}

Table 3 Mean weight of retained lung dust and coal, and mean percentage composition of retained dust (with standard deviations) for men presenting without small rounded opacities or with type $p, q$, or $r$-reader 3

\begin{tabular}{|c|c|c|c|c|c|c|c|}
\hline Opacity & No of men & Dust (g) & Coal $(g)$ & $\%$ Coal & \% Ash & $\%$ Quartz & $\%$ Kaolin + mica \\
\hline $\begin{array}{l}0 / 0 \\
\mathrm{p} \\
\mathrm{q} \\
\mathrm{r}\end{array}$ & $\begin{array}{r}105 \\
23 \\
102 \\
27\end{array}$ & $\begin{array}{l}13 \cdot 0(12 \cdot 0) \\
24 \cdot 9(11 \cdot 0) \\
18 \cdot 7(11 \cdot 0) \\
18 \cdot 2(7 \cdot 7)\end{array}$ & $\begin{array}{r}9.3(9.6) \\
18 \cdot 4(10 \cdot 8) \\
11 \cdot 7(10 \cdot 0) \\
10.3(8 \cdot 2)\end{array}$ & $\begin{array}{l}68.3(15.0) \\
70.5(17.2) \\
59.9(20.0) \\
53.7(23.3)\end{array}$ & $\begin{array}{l}\left.\begin{array}{l}31 \cdot 7 \\
29 \cdot 5 \\
40 \cdot 1 \\
46 \cdot 3(15 \cdot 0) \\
4(20 \cdot 0) \\
(23)\end{array}\right)\end{array}$ & $\begin{array}{l}5 \cdot 2(3 \cdot 1) \\
5 \cdot 0(3 \cdot 9) \\
7 \cdot 2(4 \cdot 6) \\
8 \cdot 0(4 \cdot 8)\end{array}$ & $\begin{array}{l}21 \cdot 1(9 \cdot 7) \\
20 \cdot 1 \\
26 \cdot 5(11 \cdot 1) \\
31 \cdot 7(13 \cdot 4)\end{array}$ \\
\hline
\end{tabular}

obscure any specific associations between $\mathrm{r}$ opacities and retained dust.

For all readers $p$ opacities were associated with a higher mass of retained lung dust which generally showed a higher proportion of coal and lower proportion of non-coal mineral than was seen for the other types of opacity (table 3 ). The proportion of non-coal mineral (ash) was greatest in lungs showing $r$ opacities. This observation that both the mass and composition of lung dust might afford some distinction between types of opacity was confirmed using discriminant analysis whereby the linear combination of dust variables which best characterised the differences between the types was found. Radiographs showing $p$ opacities were associated with the highest mean mass of retained dust in both coal rank groups (fig 2). In general $r$ opacities were associated with a igher proportion of ash in retained dust than other opacity types in each rank group. Nevertheless, the differences between ranks were greater than those between types of opacity, all opacity types in the low rank group having a higher proportion of ash in lung dust than $r$ opacities in the high rank group (fig 3 ).

\section{ASSOCIATION BETWEEN TYPE OF OPACITY AND} THE PRESENCE OF EMPHYSEMA

Emphysema data were available for 256 of the 261 subjects. Using the average radiographic classification they were divided into four groups; those not showing small opacities, those with small rounded opacities only, those with small irregular opacities only, and those showing both types. Half the men without radiographic opacities showed some emphysema. When small irregular opacities were present about $90 \%$ of the lungs showed emphysema (table 4). If small rounded opacities alone were present $60 \%$ of the lungs on average showed emphysema.

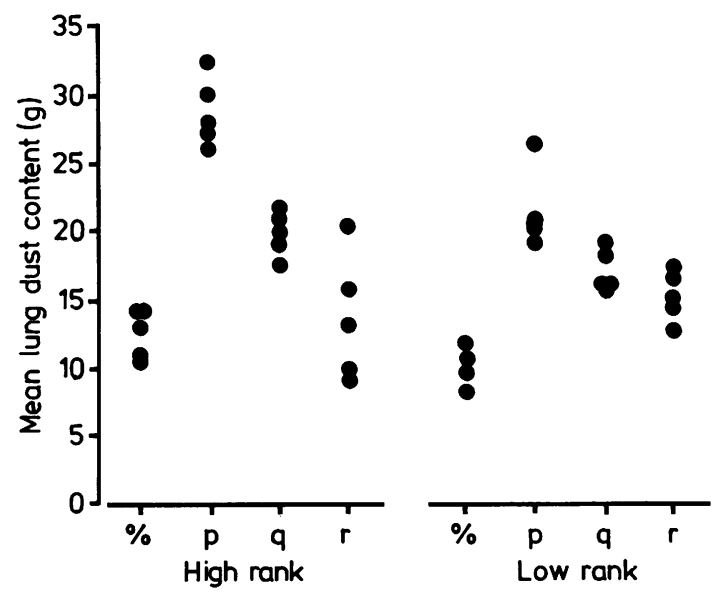

Fig 2 Mean lung dust content for category $0 / 0$ and for each type of small rounded opacity. Subjects are divided by coal rank and results shown for five readers. 
Comparison of radiographic appearances with associated pathology and lung dust content in a group of coalworkers

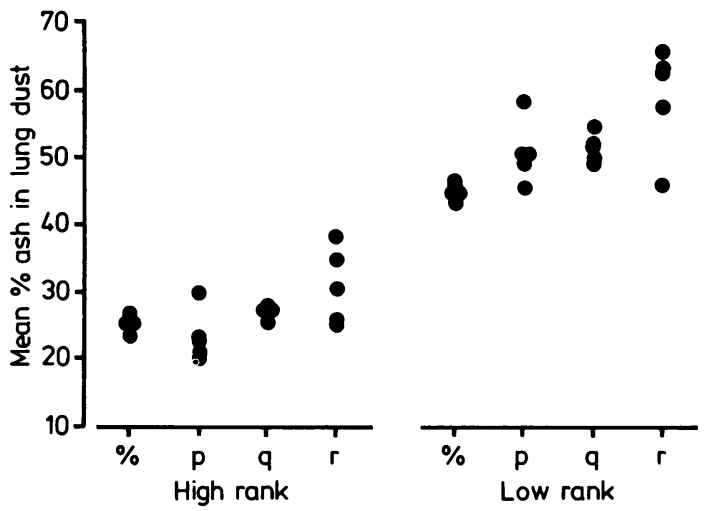

Fig 3 Mean percentage ash in retained dust for category $0 / 0$ and for each type of small rounded opacity. Subjects are divided by coal rank and results shown for five readers.

An "average" opacity type was produced for 131 radiographs showing small rounded opacities. Emphysema was present in the lungs of $90 \%$ of the

Table 4 Proportion of specimens showing emphysema considered by type of radiographic opacity present. (Number of men in each group shown in parentheses)

\begin{tabular}{l}
\hline \multicolumn{1}{c}{$\begin{array}{l}\text { No of } \\
\text { opacities }\end{array}$} \\
SRO only SRO \\
SIO
\end{tabular}

Table 5 Proportion of specimens showing emphysema considered by the size of small rounded opacity presenting radiographically. (Number of men in each group shown in parentheses)

\begin{tabular}{llll}
\hline & $p$ & $q$ & $r$ \\
\hline $\begin{array}{l}\text { All men with simple } \\
\text { Mneumoconiosis only }\end{array}$ & $92 \%(37)$ & $66 \%(80)$ & $57 \%(14)$ \\
pneu(18) & $61 \%(41)$ & $*$ \\
\hline *Only two men with r opacities were classified as simple \\
pneumoconiosis; one showed emphysema.
\end{tabular}

group with $\mathrm{p}$ type small rounded opacities whereas $60 \%$ of those presenting with $q$ or $r$ opacities showed emphysema (table 5).

\section{PATHOLOGICAL BASIS OF SMALL ROUNDED OPACITIES}

In the group of 31 subjects studied the mean profusion scores for each opacity type ( $p, q$, and $r)$ were similar. The results of the pathological examination are summarised in table 6 . The figures given are the mean of seven values produced by the four observers. While intraobserver variation was small, interobserver variation was evident, particularly for counts of dust foci. These differences were a matter of interpretation of lesions, regarded by some observers as single and by others as composite.

Table 6 shows that although dust foci were present in subjects without radiographic opacities, the lungs showed fewer foci than were found for men who had opacities, and these foci tended to be small and were rarely palpable. For half the subjects categorised as showing $p$ type opacities the pathological appearances consisted predominantly not of discrete dust foci but rather of an extensive lattice work of tissue made rigid by the presence of dust.

Where dust foci could be counted the mean number per zone when opacities were of the $p$ or $q$ type was similar, being 81 and 95 respectively (table $6)$. Fewer dust foci per zone were associated with $r$ opacities, the mean value being 41 . There were striking differences in the proportion of foci which were palpable as nodules depending on the type of opacity. When p opacities were observed, on average only $16 \%$ of dust foci in the corresponding lungs were palpable, whereas for $r$ opacities more than half the foci were palpable.

For all three types of opacity the greatest proportion of the total dust foci measured between 1.5 and $3 \mathrm{~mm}$ but examination of the size distributions of palpable nodules showed differences which related to opacity type. For subjects showing $p$ type opacities $75 \%$ of nodules were evenly divided between the $<1.5 \mathrm{~mm}$ and the $1.5-3.0 \mathrm{~mm}$ size ranges. When $q$ opacities were recorded half the

Table 6 Mean counts (and standard deviations) of all dust lesions and of nodules in lung zones showing specific types of small rounded opacity

\begin{tabular}{|c|c|c|c|c|c|c|c|c|c|c|}
\hline $\begin{array}{l}\text { Radiographic } \\
\text { classification } \\
\text { (No of subjects) }\end{array}$ & $\begin{array}{l}\text { Mean No of } \\
\text { dust foci/zone }\end{array}$ & $\begin{array}{l}\text { Percentage } \\
\text { of all foci } \\
<1.5 \mathrm{~mm}\end{array}$ & $\begin{array}{l}\text { distribution } \\
\text { by size } \\
1.5-3 \mathrm{~mm}\end{array}$ & $>3 \mathrm{~mm}$ & $\begin{array}{l}\text { Mean No of } \\
\text { palpable nodules' } \\
\text { zone }\end{array}$ & $\begin{array}{l}\text { Mean \% of } \\
\text { dust foci } \\
\text { palpable (range) }\end{array}$ & $\begin{array}{l}\text { Percentage } \\
\text { of nodules } \\
<1.5 \mathrm{~mm}\end{array}$ & $\begin{array}{l}\text { distribution } \\
\text { by size } \\
1.5-3 \mathrm{~mm}\end{array}$ & $>3 \mathrm{~mm}$ & $\begin{array}{l}\text { Mean \% of } \\
\text { lung affected by } \\
\text { emphysema }\end{array}$ \\
\hline $\begin{array}{l}0 / 0(7) \\
{ }^{*} p(10) \\
{ }^{*} q(9) \\
r(5)\end{array}$ & $\begin{array}{l}28(21) \\
81(59) \\
95(48) \\
41(21)\end{array}$ & $\begin{array}{l}47 \\
28 \\
26 \\
23\end{array}$ & $\begin{array}{l}36 \\
44 \\
62 \\
49\end{array}$ & $\begin{array}{l}17 \\
28 \\
12 \\
28\end{array}$ & $\begin{array}{l}<1 \\
13(15) \\
41(31) \\
23(18)\end{array}$ & $\begin{array}{l}0 \\
16(5-48) \\
43(11-75) \\
56(32-94)\end{array}$ & $\begin{array}{l}\overline{37} \\
31 \\
10\end{array}$ & $\begin{array}{l}\overline{38} \\
54 \\
48\end{array}$ & $\begin{array}{l}\overline{23} \\
15 \\
41\end{array}$ & $\begin{array}{r}9 \\
18 \\
13 \\
8\end{array}$ \\
\hline
\end{tabular}

FFor five $\mathrm{p}$ cases and one $\mathrm{q}$ case total dust foci could not be counted although it was possible to count palpable nodules. 
palpable lesions were in the $1.5-3.0 \mathrm{~mm}$ range and for $\mathrm{r}$ opacities, $48 \%$ of palpable lesions were in the $1.5-3.0 \mathrm{~mm}$ size range and a further $41 \%$ were more than $3 \mathrm{~mm}$ in size (table 6).

The proportion of lung showing emphysema was also related to type of opacity. Lungs presenting with $p$ opacities showed the most emphysema whereas $r$ opacities were associated with the least, being similar to lungs without radiographic evidence of disease (table 6).

Three shapes of dust deposit were observed (table 7), and there was good agreement between observers about the predominant shape in each subject. Type a (stellate) was usually associated with a central palpable lesion of less than $3 \mathrm{~mm}$ in size; most were considerably smaller than this. Circumscribed nodules (type c) were commonly larger than $3 \mathrm{~mm}$ and were characteristic of subjects presenting with $r$ opacities. The b lesion, showing a crenated border, predominated in subjects with $\mathrm{q}$ type opacities. More than half the subjects with p opacities showed the classic stellate lung lesions (type a). Where the predominant lesion was of type $b$ the difference between $p$ and $q$ subjects was one of size, $p$ opacities being associated with smaller lesions than $q$ opacities.

Examination of histological material confirmed the differences in lesion size and shape observed macroscopically. In lungs categorised as $0 / 0$ dust
Table 7 Twenty four lungs presenting as typical small rounded opacities divided by radiographic type and dust lesion shape

\begin{tabular}{llll}
\hline Opacity type & $a$ & $b$ & $c$ \\
\hline $\mathrm{p}$ & 6 & 4 & - \\
$\mathrm{q}$ & 2 & 7 & $\overline{5}$ \\
$\mathrm{r}$ & - & - & 5 \\
\hline
\end{tabular}

macules were present but individual deposits in relation to respiratory bronchioles were generally rather small, reaching a maximum thickness of $0.75 \mathrm{~mm}$. Lungs presenting $\mathrm{p}$ type opacities contained larger numbers of dust macules. In addition a proportion of the dust foci showed a measurable solid centre of 1.0 to $1.5 \mathrm{~mm}$ and were associated with focal emphysema, with dust accumulation accentuating the peripheral extensions of the stellate lesion (fig 4). The peripheral extensions of the larger lesions associated with q opacities appeared shorter (fig 5) and some showed central fibrosis with relatively less dust in this area than at the periphery. The largest lesions often showed some evidence of central degeneration. In subjects showing $\mathrm{r}$ opacities palpable nodules predominated and these ranged in size from $2 \mathrm{~mm}$ to $10 \mathrm{~mm}$, commonly showing distinct peripheral and central zones. In the five examined here the picture was either that induced by a high quartz content of the dust or that seen in Caplan's

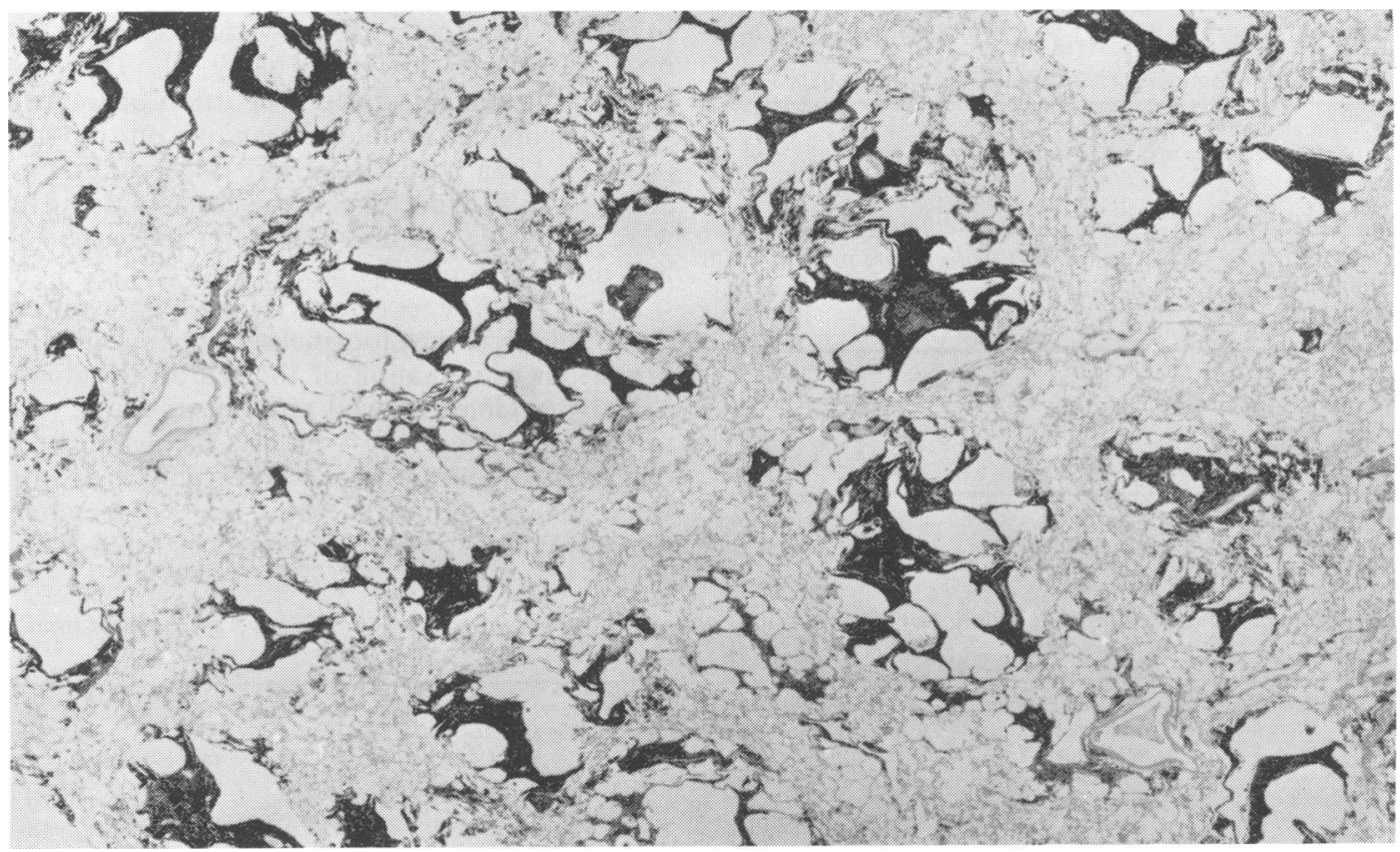

Fig 4 Classic centriacinar stellate dust lesions presenting radiographically as p type opacities $(\times 11 \cdot 5$. 
Comparison of radiographic appearances with associated pathology and lung dust content in a group of coalworkers

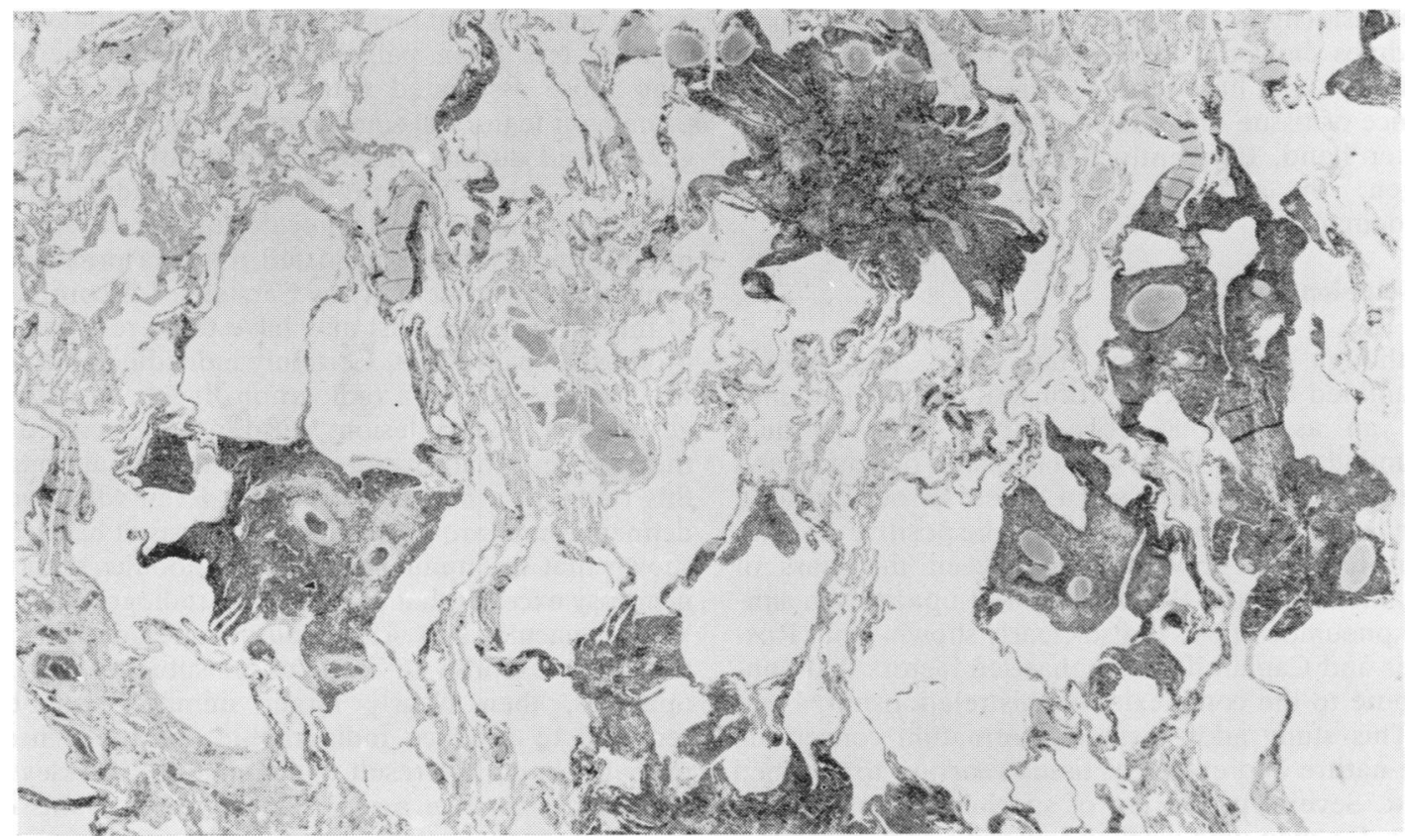

Fig 5 Larger dusted lesions showing a crenated border and presenting as q type opacities. $(\times 11 \cdot 5$.

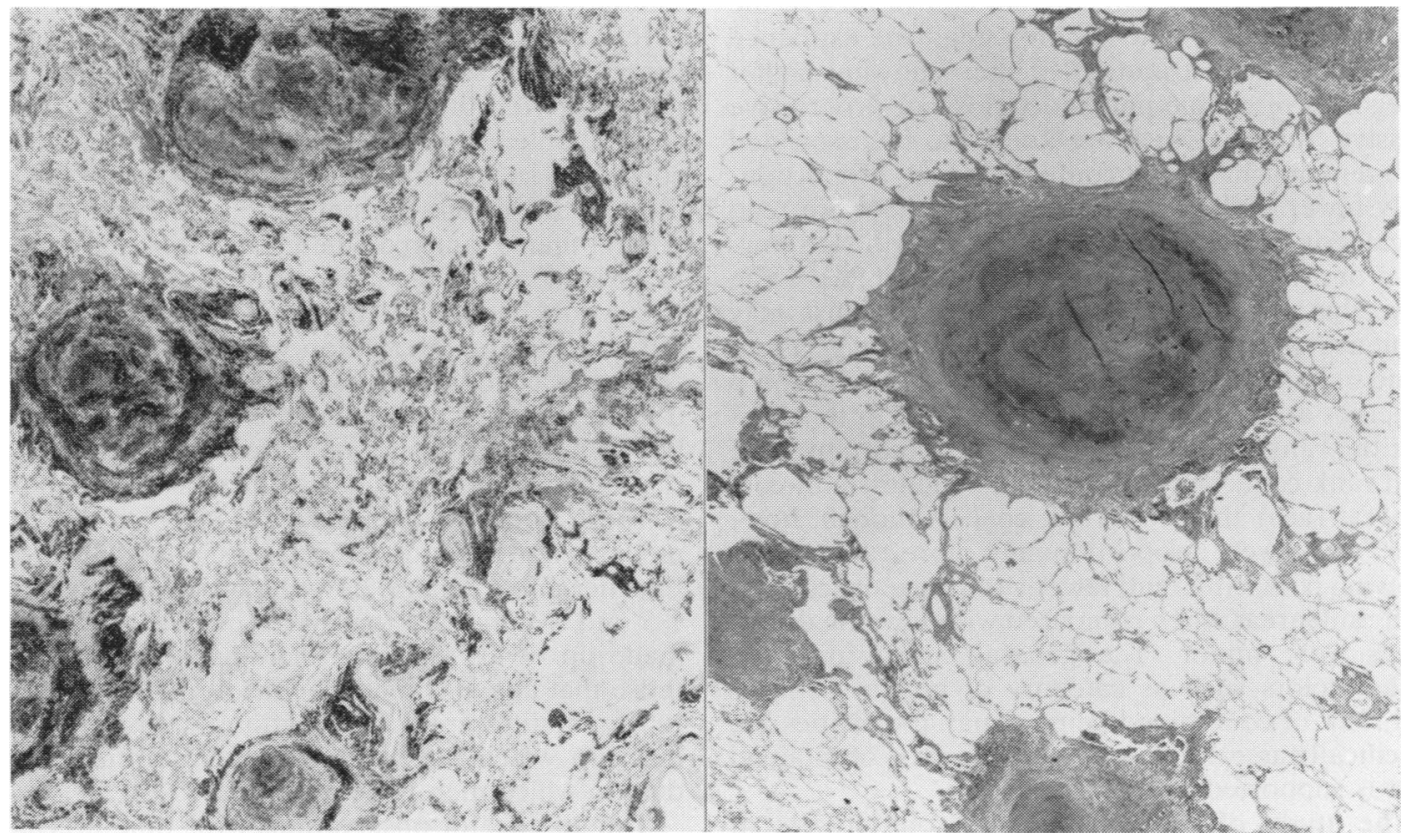

Fig 6 Two examples of nodular lesions that may present as $r$ opacities. On left, dust "tidemarking." typical of Caplan's syndrome is seen. Nodules on right were associated with lung dust containing $18 \%$ quartz. $(\times 11.5$. 
syndrome and associated with the rheumatoid diathesis (fig 6). In the former the central regions of nodules showed a characteristic whorling pattern of collagen with little visible dust and seldom any evidence of tissue breakdown. Caplan's lesions, on the other hand, frequently displayed necrosis of collagen, in addition to the classic peripheral "tidemarking" by dust.

\section{Discussion}

Although opacity type has been less closely examined than opacity profusion, there is evidence for an association between both type $p$ small rounded opacities ${ }^{8}$ and small irregular opacities ${ }^{9}$ and the presence of emphysema. These associations are confirmed in the present study. The positive association reported previously ${ }^{4}$ between the mass of retained dust and the profusion of opacities in simple pneumoconiosis is also clearly shown. Both Rossiter and Caplan have emphasised factors that contribute to the complexity of this relationship. ${ }^{67}$

This study adds further information concerning the nature and extent of tissue reaction to retained dust. Several points are of special interest. One is that, for men who worked low rank coal, there is a less distinct association between increasing profusion of small rounded opacities and an increase in the amount of retained dust. A second is that, depending on the predominant type of small rounded opacity present, the amount of dust in the lungs differs. The latter finding might be explained by an uneven distribution of men showing higher categories of simple pneumoconiosis or progressive massive fibrosis, which are known to be associated with a higher lung dust content. In fact, proportionately fewer radiographs with $p$ opacities were read as category 2 or higher compared with those showing $q$ or $r$, and most of the $r$ cases showed PMF. The view that the composition of retained dust may influence the degree of radiographic change is, to some extent, reflected in the association between $p$ opacities and dust of high coal content. In this context the rank of coal mined may be important since high rank coal contains more coal and less non-coal mineral (ash) than low rank coal. Although, however, there were proportionately more radiographs showing $p$ opacities and fewer showing $q$ opacities in high rank areas when compared with low, the differences were minor. The general conclusion that, other factors such as category of pneumoconiosis and rank of coal mined being equal, $p$ opacities are specifically associated with a higher mass of retained dust is supported.

The study of the pathological counterparts of small rounded opacities goes some way to offer a rationale for these differences. Lungs presenting with $p$ opacities had foci of dust deposition that were smaller, less often palpable, and more numerous than those associated with $\mathrm{r}$ opacities. Indeed, a prominent feature of some $p$ specimens was a rather generalised dusting of tissue not clearly separated into dust foci. The production of radiographic opacities in such subjects may depend on the superimposition of lattices of dusted tissue, a possibility confirmed experimentally by Carstairs. ${ }^{15}$ A corollary of this is that more dust may have to be retained to produce a given effect. Certainly individual macules will not be seen on a radiograph. It has been suggested that solitary lesions will not be visualised if they are less than $3 \mathrm{~mm}$ in diameter, ${ }^{16}{ }^{17}$ although this refers to a non-dusted lesion. Even when well defined lesions are present, as in silicosis, it has been shown that the number of silicotic nodules seen at necropsy exceeds that predicted by radiography. ${ }^{18} 19$ Where macules and very small fibrotic nodules are the only response to dust, as in subjects with $p$ opacities, then clearly larger numbers will be required to produce radiographic opacities, these probably being the result of summation. Ruckley $e t$ al found a positive association between counts of any dust foci in the lung and the profusion of opacities $(r=0.43) . "$ When the number of foci was recorded for specific size ranges, opacity profusion was more closely associated with nodules than with macules (for nodules $>3 \mathrm{~mm} \mathrm{r}=0.5-0.8$ for five radiographic readers).

Radiographs showing $r$ opacities were the least common. The study of a small group of pure examples suggested that this group will always include a considerable proportion of subjects with nodular conditions such as silicosis or Caplan's syndrome. As most of the lesions present were palpable and often greater than $3 \mathrm{~mm}$ in diameter they were more likely to produce a radiographic image and, overall, less dust would be required for a given effect. ${ }^{5}$ Nevertheless, the general association with a dust of high ash content was not striking in men showing $r$ opacities drawn from high rank mining areas. The difference between men showing $r$ opacities from high and low rank areas therefore requires further clarification.

The $\mathrm{q}$ opacity is generally regarded as the commonest expression of coalworkers' pneumoconiosis. Fletcher and Oldham, describing opacities between 1.5 and $3 \mathrm{~mm}$, said they were of two types, those made up of aggregations of minute opacities, and those that appear homogeneous. ${ }^{20}$ These types may represent different tissue reactions to dust within the q group which depend on the composition of the dust to which men were exposed.

The absence of observations over time precludes any judgment about changes from one opacity type 
to another for an individual. Lange et al suggested that this occurs only in a small proportion of men, although they noted that $\mathrm{p}$ opacities were more common in younger men. ${ }^{21}$ In the present study group, for whom the average age was 65 , one might assume that the opacity type was a characteristic of a man's response to dust. Whereas a study of "pure" opacity type cases is of interest, for most men the radiograph will show opacities covering a range of sizes that reflect the age of dust lesions and perhaps exposure to dusts of different composition.

Although effective control of mass exposure remains a primary aim it becomes increasingly clear that the composition of the dust that a man breathes may be of significance. We have shown that the increase in opacity profusion for subjects drawn from low rank areas is not simply associated with an increase in the mass of retained dust but closely relates to the ash component of that dust. The results suggest that, in terms of dust mass, less may be required for a given radiographic effect when the ash content of the dust is high. This conclusion is in agreement with Casswell et $a^{5}$ who found that, weight for weight, the contribution of the mineral component of dust to the relationship with radiological appearances was greater than that of coal. Other work in this necropsy study " suggests that the clearance of coal and ash components of dust may differ, and it is possible that some increase in radiographic change is attributable to a continuing tissue reaction to dust held in the lung.

We are grateful to the staff of the pneumoconiosis medical panels and several hospitals for supplying necropsy material and some chest radiographs.

Dr J G Bennett, Dr J Burns, Dr J A Dick, Dr D J Thomas, and Dr J S Washington of the National Coal Board gave valuable time to provide radiographic readings.

Many staff of the Institute of Occupational Medicine gave skilled help in this study, which was jointly funded by the National Coal Board and the Commission of the European Communities.

Requests for reprints to: V Anne Ruckley, Institute of Occupational Medicine, 8 Roxburgh Place, Edinburgh EH8 9SU.

\section{References}

' Jacobsen M, Rae S, Walton WH, Rogan JM. The relation between pneumoconiosis and dust exposure in British coal mines.
In: Walton WH, ed. Inhaled particles III. Old Woking, Surrey: Unwin Bros, 1971:903-17.

${ }^{2}$ Reisner MTR. Results of epidemiological studies of pneumoconiosis in West German coal mines. In: Walton WH, ed. Inhaled particleśs III. Old Woking, Surrey: Unwin Bros, 1971:921-9.

${ }^{3}$ Hurley JF, Burns J, Copland L, Dodgson J, Jacobsen M. Coalworker's simple pneumoconiosis and exposure to dust at 10 British coalmines. Br J Ind Med 1982;39:120-7.

${ }^{4}$ Rivers D, Wise ME, King EJ, Nagelschmidt G. Dust content, radiology, and pathology in simple pneumoconiosis of coalworkers. Br J Ind Med 1960;17:87-108.

${ }^{5}$ Casswell C, Bergman I, Rossiter CE. The relation of radiological appearance in simple pneumoconiosis of coal workers to the content and composition of the lung. In: Walton WH, ed. Inhaled particles III. Old Woking, Surrey: Unwin Bros, 1971:713-24.

- Rossiter CE. Relation of lung dust content to radiological changes in coal workers. Ann NY Acad Sci 1972;200:465-77.

7 Caplan A. Correlation of radiological category with lung pathology in coal-workers' pneumoconiosis. $\mathrm{Br} J$ Ind Med 1962;19:171-9.

${ }^{8}$ Hankinson JL, Palmes ED, Lapp NL. Pulmonary air space size in coal miners. Am Rev Respir Dis 1979;119:391-7.

${ }^{9}$ Lyons JP, Ryder RC, Cambell H, Clarke WG, Gough J. Significance of irregular opacities in the radiology of coalworkers' pneumoconiosis. Br J Ind Med 1974;31:36-44.

${ }^{10}$ International Labour Office. International classification of radiographs of pneumoconioses, 1971. Geneva: ILO, 1972. (Occupational Safety and Health series No 22.)

"Ruckley VA, Chapman JS, Collings PL, et al. Autopsy studies of coalminers' lungs-phase II. Edinburgh: Institute of Occupational Medicine, 1981. (IOM report TM/81/18.)

${ }_{12}$ Heard BE. Pathology of chronic bronchitis and emphysema. London: J and A Churchill, 1969.

${ }^{13}$ Guest L. The recovery of dust from formalin-fixed pneumoconiotic lungs: a comparison of the methods used at SMRE. Ann Occup Hyg 1976; 19:37-47.

${ }^{14}$ Dodgson J, Whittaker $W$. The determination of quartz in respirable dust samples by infrared spectrophotometry-I. The potassium bromide disc method. Ann Occup Hyg 1973; 16:373-87.

is Carstairs LS. The interpretation of shadows in a restricted area of a lung field on the chest radiograph. Proceedings of the Royal Society of Medicine 1961;54:978-80.

${ }^{16}$ Greening RR, Pendergrass EP. Post mortem roentgenography with particular emphasis on the lung. Radiology 1954;62:720-5.

${ }^{17}$ Spratt JS, Ter-Pogossian M, Long RTL. The detection and growth of intra-thoracic neoplasms: the lower limits of radiographic distinction of the antemortem size, the duration and the pattern of growth as determined by direct mensuration of tumour diameters from random thoracic roentgenograms. Arch Surg 1963;86:283-8.

18 Theron GP, Walters LG, Webster J. The international classification of radiographs in the pneumoconioses. Medical Proceedings (Johannesburg) 1964;10:352-4.

${ }^{19}$ Heitzman ER. The lung. Radiologic-pathologic correlations. St Louis: CV Mosby Co, 1973.

${ }^{20}$ Fletcher CM, Oldham PD. The problem of consistent radiological diagnosis in coalminers' pneumoconiosis. An experimental study. Br J Ind Med 1949;6:168-83.

${ }^{21}$ Lange R, Worth G, Smidt U, Stahlmann W. Longitudinal study of the radiology of coal workers' pneumoconiosis. I. Small and large opacities. Int Arch Occup Environ Health 1980;45: 1-13. 